\title{
EVANGÉLICOS E ÉTICA NO BRASIL
}

Júlio Paulo Tavares Zabatiero

\section{RESUMO}

O objetivo deste artigo é a análise das categorias fundantes das diversas práticas éticas de evangélicos no Brasil (por evangélicos entendo aqui as diversas igrejas e organizações que vinculam sua origem ao movimento missionário norteatlântico dos séculos XIX e XX). A hipótese fundamental é a de que a ética de evangélicos no Brasil é muito mais caracterizada pela "brasilidade" do que pela tradição bíblica a que evangélicos aludem quando perguntados sobre por que fazem o que fazem. Tento traçar uma breve história da atitude ética, que começa como valorização quase que exclusiva da ética pessoal focada na diferenciação entre evangélicos e outros cristãos, passando por uma valorização, algo utilitarista, da dimensão política da ética, chegando a uma situação relativamente plural, mas centrada ainda nos chamados valores pessoais e individuais, sem conseguir transcender os elementos de "brasilidade" presentes desde a chegada dos primeiros missionários protestantes. A partir dessa revisão, passo a propor um caminho teologicamente mais viável para a atitude e prática ética de evangélicos. Baseada em uma cristologia de 
corte latino-americano, sustento que os eixos de uma ética evangélica são a liberdade e o amor - a liberdade de todas as forças que escravizam o ser humano, históricas ou transcendentais - para a vivência efetiva e a prática consequente do amor a Deus acima de tudo o mais, concretizado no amor ao próximo (a pessoa e os grupos sociais necessitados, injustiçados) como expressão coerente do amor a si mesmo. Um tipo de ética que transcenda a ética do dever e a ética do conformismo com o mundo.

\section{ABSTRACT}

The goal of this article is to analyze the founding categories of the several evangelical ethics in Brazil (evangelicals means the churches and organizations whose origins can be traced to the North-Atlantic missionary movement of the XIX and early XX centuries). The basic hypothesis is that the Brazilian evangelical ethics bears more resemblance to the cultural ethos of our country (brasilidade) than to the Biblical ethics that evangelicals allude to as their rule of faith and practice. I try to trace the historical path from an individual personal ethics of duty, to a rather utilitarian political ethics, coming to a relatively plural situation still centered on an individual duty ethics. Along this history, the marks of the brasilidade make themselves visible all the time. From this survey, I develop an effort to design a theological path more coherent to the so-called Biblical ethics, founded on a Christological concept. I design an ethics centered on freedom - from all the forces, historical and transcendent, that make humanity slave, to a thorough practice of love - to God above all - manifested by the love to the neighbor (the need and injustice person and social groups) as the other face of the love to himself/herself. 


\section{INTRODUÇÃO}

A ética evangélica ${ }^{1}$, ao longo da nossa história, foi predominantemente uma moralidade pessoal. Ainda que marcada por uma atitude crítica em relação a comportamentos específicos, considerados pecaminosos, as igrejas evangélicas brasileiras não conseguiram se diferenciar significativamente do ethos nacional. Com esta afirmação estou me distanciando da familiar tese de que as igrejas fundadas por missionários americanos nunca se contextualizaram na cultura brasileira. A chamada "falta de contextualização" pode explicar, a meu ver, apenas fenômenos delimitadores de fronteiras da identidade de evangélicos brasileiros (predominantemente morais e doutrinários), mas não é capaz de dar conta da brasilidade tão presente nesse segmento do Protestantismo quanto no povo brasileiro em geral ${ }^{2}$. Podemos constatar entre evangélicos a presença de atributos culturais "brasileiros", conforme a descrição de Gilberto Freyre, retomada por Jessé Souza:

Importa perceber que a categoria estruturante de patriarcalismo em Freyre, com seus atributos de personalismo, familismo e privatismo, possui dois princípios complementares aparentemente contraditórios. Esses dois princípios complementares são os aspectos despótico e segregador, de um lado, e os

${ }^{1} \mathrm{O}$ termo evangélico, hoje em dia, não é muito útil para identificar igrejas ou movimentos teológicos no protestantismo brasileiro. Como este texto brotou de uma palestra que me pedia o uso do termo, mantenho-o no escrito. Por evangélicos, neste texto, refiro-me principalmente às igrejas do Protestantismo de Missão - batistas, presbiterianas, metodistas, congregacionais.

${ }^{2}$ Fica sem discutir a complexa questão da unidade e diversidade da cultura brasileira. 
"democrático" e inclusivo, do outro. A especificidade do patriarcalismo brasileiro, sua longevidade até nossos dias, reside na dialética entre esses dois polos, desde que o princípio estruturante personalista, familista e privatista seja mantido. ${ }^{3}$

Os atributos do patriarcalismo acima descrito em curtos traços são facilmente encontrados no modo de ser da maioria dos evangélicos brasileiros e são uma força cultural estruturadora da ética evangélica. Por isso, vejo a ética evangélica brasileira como constituída por uma intensa ambiguidade: o reconhecimento ético-teológico de que devemos ser "diferentes" é acompanhado pelo conservadorismo ético-cultural nos âmbitos familiar, social e político, o que não nos permite fazer essa "diferença" ir muito além do que costumamos chamar de testemunho pessoal.

É claro que estas afirmações são generalizantes e não se aplicam a todos os casos individualmente analisáveis. Apresento-as apenas para formar um ponto de partida para a reflexão sobre o tema da ética. Minha premissa básica é: não é possível pensar em ética cristã de forma desvinculada da teologia: "a ética cristã é fundamentalmente a exploração da importância prática da visão teológica revelada na narrativa bíblica"4. Sem teologia, a ética das comunidades se dilui em busca de códigos de conduta diferenciadores da sociedade não-evangélica.

${ }^{3}$ SOUZA, Jessé. "Democracia racial e multiculturalismo: a ambivalente singularidade cultural brasileira". In: Estudos Afro-Asiáticos. Rio de Janeiro, n. 38, dezembro de 2000, pp. 135-155. http://www.scielo.br/scielo. php?script=sci_arttext\&pid=S0101-546X2000000200007\&lng=pt\&nrm $=$ iso.

${ }^{4}$ GRENZ, Stanley. A busca da moral. Fundamentos da ética cristã. São Paulo: Vida, 2006, p. 348. 
Há muitas vias possíveis para desenvolver o tema aqui proposto, nenhuma das quais poderá ser exaustiva. Preferi optar por um caminho motivado pela estrutura do discernimento, e abordar três aspectos primordiais na tentativa de construir uma ética evangélica relevante para nossos tempos. Os dois primeiros são descritivos - correspondem ao movimento analítico do discernimento. $\mathrm{O}$ terceiro aspecto é propositivo, e configura-se como o movimento construtivo do discernimento cristão.

\section{Mutações recentes na ética de evangélicos no Brasil}

Durante a maior parte da sua história, as igrejas evangélicas no Brasil foram numericamente pouco significativas, com reflexos imediatos sobre seu lugar cultural e político no país. Durante esse período, praticamente incapaz de afetar significativamente a vida pública, a posição mais típica das igrejas era a de ser uma espécie de contracultura, de "consciência" da população. Uma série de negações caracterizava o ethos evangélico: não beber, não fumar, não adulterar, não divorciar, etc. Positivamente, a sociedade, em geral, reconhecia em evangélicos um exemplo de honestidade, integridade pessoal, esforço profissional, pessoas confiáveis. A ética evangélica pode ser descrita como uma ética individual de cumprimento de deveres ${ }^{5}$, uma

${ }^{5}$ Infelizmente, esse tipo de visão ética dá valor a uma leitura que Foucault faz da ética cristã, equivocada no tocante à Escritura, mas correta no tocante à maneira como as instituições eclesiásticas cristãs, em geral, no Ocidente, concebem a ética: "no cristianismo, com a religião do texto, a idéia de uma vontade de Deus, o princípio de uma obediência, a moral assumia muito mais a forma de um código de regras". (FOUCAULT, Michel. "Uma estética da existência". In: MOTTA, Manoel B. da (org.). Foucault: Ética, sexualidade, política. Ditos \& Escritos V. Rio de Janeiro: Forense Universitária, 2004, p. 290.) 
ética culturalmente patriarcalista, com todas as suas ambiguidades, na qual predominam valores e comportamentos mais típicos de classe média ${ }^{6}$, com escassa participação na vida pública do país, praticamente restringindo-se a defender os seus direitos institucionais como religião minoritária ${ }^{7}$.

Hoje em dia, mesmo com o contingente numérico bastante significativo (cerca de $20 \%$ da população), e com o crescimento de formas neoliberais de experiência e instituição cristãs, a ética de evangélicos continua sendo primariamente uma questão de regras de conduta e de restrição de comportamento. Pesquisas recentes indicam que a pregação ética na IURD, por exemplo, está centrada na defesa da família nuclear, do trabalho, da honestidade e da submissão da esposa ao marido ${ }^{8}$. A diferença é que é o ethos neoliberal dessa denominação ajuda as pessoas a se acomodarem melhor ao consumismo e individualismo de nosso século XXI. Como dado mais positivo, por outro lado, cresceu a consciência pública de evangélicos,

${ }^{6}$ Esse é o grande risco da ética cristã: a identificação com um ethos, com uma forma de vida, o que concretiza a falha em vivenciar o fato de que "a ética cristã é uma possibilidade impossível". (THIELICKE, Helmut. Theological Ethics. Foundations. Philadelphia: Fortress Press, 1966, p. 44.)

${ }^{7}$ Com base no ato criador e redentor de Deus, uma ética cristã precisa superar a busca de interesses privados: "Nas formas de vida racionais, devem se impor as orientações de ação que superem a estreiteza de visão dos meros interesses privados; o interesse que cada pessoa tem por sua auto-realização deve estar em consonância com o interesse de todos". (HABERMAS, Jürgen. "Racionalidad de uma forma de vida". In: REDONDO, Manuel J. (org.) Escritos sobre moralidad y eticidad. Barcelona: Paidós, 1991, p. 83.)

${ }^{8}$ BOVKALOVSKI, Etiane C. Homens e mulheres de Deus: modelos de conduta ética da IURD (1986-2001). Tese de doutorado defendida junto ao PPG em História da Universidade Federal do Paraná. Curitiba, 2005, inédita. 
e se percebe uma presença mais intensa no mundo complexo da política - tendendo, porém, em alguns casos, ao modelo de Cristandade - ou seja, mantendo a ambiguidade patriarcalista entre os polos do despotismo e da democracia?

Ao mesmo tempo em que cresce a consciência social e política de evangélicos, a atitude das novas gerações evangélicas, com relação à ética pessoal, tem sido a de um certo relaxamento de costumes sexuais em relação ao período anterior (mas não a recusa de uma ética de deveres), e um crescimento do consumismo individualista e da indiferença hedonista ${ }^{10}$. Mais e mais se ouve falar de corrupção, desonestidade e "escândalos" sexuais entre evangélicos. Isto chegou ao ponto em que, juntamente com questões doutrinárias, o próprio adjetivo "evangélico" se tornou motivo de problematização - a que nos referimos quando o utilizamos? Que tipo de crenças e práticas vêm à mente quando ouvimos o termo "evangélicos" hoje em dia? Essa "crise" se manifesta especialmente como: (1) iden-

9 "O protestantismo não-pentecostal no Brasil no Brasil era principalmente fruto da obra missionária das igrejas européias e norte americanas. A ligação com as igrejas emissoras ainda era muito forte nessa ocasião [anos 1960], e graças à influência dessas igrejas, a maioria dos líderes protestantes no Brasil e em alguns países da América Latina ou apoiaram as ditaduras ou, o que dá no mesmo, se omitiram" (LOPES, Orivaldo P. "Protestantismo, democracia e violência". In: FERREIRA, João C. L. (org.). Novas perspectivas sobre o Protestantismo brasileiro. São Paulo: Fonte \& Paulinas, 2009, p. 179.

${ }^{10}$ É interessante constatar, por motivos bem diversos, situação parecida nos tempos de Calvino: "Existem hoje em dia cristãos semelhantes àqueles estóicos que consideram um mal, não somente gemer e chorar, mas também entristecer-se e preocupar-se ou mostrar solicitude. Essas opiniões anti-sociais em geral procedem de pessoas ociosas, que, dedicando-se mais a especular que a pôr mãos à obra, só podem produzir fantasias como essa." (CALVINO, João. As Institutas da Religião Cristã: edição especial com notas para estudo e pesquisa. São Paulo: Cultura Cristã, 2006, vol. 4 p. 207.) 
tificação prática da experiência cristã com formas de êxtase religioso, a partir do sucesso numérico de igrejas e comunidades caracterizadas, por falta de nome melhor, de neopentecostais, que estabelecem o tom para o conjunto das denominações evangélicas; (2) a incapacidade destas novas gerações de evangélicos se desenvolverem rumo à maturidade cristã, vivenciando um dualismo entre experiência religiosa e vivência ética ${ }^{11}$; e (3) a renovação de comportamentos e discursos fundamentalistas, com seu acentuado discurso de reafirmação de valores morais tradicionais, em oposição ao que consideram a licenciosidade sexual e ética dos tempos atuais.

\section{A nova valorização da dimensão sócio-política da ética cristã}

Desde sua chegada ao Brasil, as igrejas evangélicas praticavam a evangelização e algum tipo de obra social. Primeiramente, dedicaram-se a abrir escolas e hospitais e, ao longo da história, passaram a enfatizar a prática da assistência social, com ações de diversos tipos (creches, orfanatos, asilos,

${ }^{11}$ Esse dualismo faz com que o ethos evangélico não se distingua significativamente do ethos contemporâneo. Uma boa descrição desse ethos nos é oferecida por Lipovetsky: "Não negamos que a ética, após um período de relativo ocaso, tenha sido agora reconduzida a um pedestal. Entretanto, o esquema da restauração da moral, por demais simplista, admite como verdadeira a idéia de uma volta idêntica ao que era antes, quando, na verdade, justamente o mais característico é o distanciamento do sistema em que a moral funcionava no passado, uma diferença no registro social dos valores". (LIPOVETSKY, Giles. A sociedade pós-moralista. O crepúsculo do dever e a ética indolor dos novos tempos democráticos. Barueri: Manole, 2005,p. XXVIIs.). Para um estudo mais detalhado do dualismo no protestantismo evangélico, ver o capítulo terceiro de ROSA, Wanderley P. O dualismo na Teologia Cristã. São Paulo Fonte Editorial \& Vitória: Faculdade Unida, 2010, p. 78-153. 
etc.), mas considerando essas ações como parte da missão, e não como expressão da ética evangélica propriamente dita. De modo geral, a partir de uma interpretação do princípio da separação entre Igreja e Estado e de certas características da prática política em nosso país, o papel de evangélicos no campo político praticamente se restringia ao voto e à defesa da democracia liberal-capitalista, como a forma de governo que possibilitaria a permanência da liberdade religiosa. Aqui e ali, porém, formas mais ousadas de visão social e política surgiam - a mais famosa delas está vinculada à famosa Conferência do Nordeste, nos anos 60, cujo tema foi "Cristo e o processo revolucionário brasileiro".

A partir dos anos 70, principalmente, ONGs, movimentos não-institucionais e entidades ecumênicas passam a enfatizar a necessidade de uma ética social e política capaz de superar a mera participação formal no processo eleitoral democrático $^{12}$. Por um lado, cresce a consciência de que evangélicos devem praticar o bem ao próximo, e crescem os projetos assistenciais, de serviço social, e de desenvolvimento comunitário. Por outro, cresce a consciência da necessidade de uma participação política mais decisiva nos processos democráticos, especialmente no âmbito da ação partidária e da disputa por cargos eletivos. Essa consciência política ainda pouco falava de participação na "esfera pública", acentuava a crítica às estruturas econômicas empobrecedoras e afirmava a necessidade de sua transformação mediante a ação do Estado. Assistência social e participação política ainda eram vistos primordialmente como expressão da missão (integral),

${ }^{12}$ Tratei com algum detalhe parte desse movimento ético-teológico em: ZABATIERO, Júlio P. T. "Um movimento teológico e sua contribuição para a transformação social. A FTL-Brasil”. In: Religião e Transformação Social no Brasil Hoje. São Paulo: Paulinas, 2007. p. 133-158. 
e não como expressão da ética. O aspecto ético destacado nesse processo de transformação evangélica era o da honestidade dos governantes, da obediência à lei, e o do patriotismo. Em outras palavras, cresce significativamente a consciência social e política da ajuda ao necessitado, inclusive com a transformação de estruturas, mas a visão ética permanece centrada na integridade e honestidade individuais, na defesa da família, e na rejeição de certas formas de comportamento considerado pecaminoso, mas, agora com alguma contestação da visão patriarcalista da sociedade.

Nesse importante processo de mudança de visão das igrejas evangélicas, o grande risco é confundir a missão (ou a ética) com um projeto político-partidário específico, o que rompe com a tensão escatológica própria ao cristianismo, e subordina a teologia à ideologia ${ }^{13}$. Que esse risco não está distante, é perceptível em discursos e ações de certas instituições denominacionais que pendem para uma atuação política ao estilo de cristandade ${ }^{14}$ - alcançar o poder para se bene-

13 "Consequentemente, o objetivo da ética não pode ser a superação da tensão, sugerindo acordos que supostamente fizessem justiça aos dois elementos da tensão. A ética deve seguir o caminho que leva a e através da tensão. [...]. O tema da ética é esse caminhar entre dois mundo. É, em sentido estrito, o tema de uma teologia a caminho, uma theologia viatorum. Ela vive sob a lei do ainda não, mas com a paz do "eis que em breve venho’ (Ap 22.20). Ética teológica é ética escatológica ou não é nada.” (THIELICKE, Helmut. Theological Ethics-Foundations. Philadelphia: Fortress Press, 1966, p. 47.)

14 "O modelo de Igreja-Cristandade foi resultante de uma concepção que se estabeleceu ao longo da Idade Média Ocidental. Partindo do conceito de sociedade sacral, os "direitos de Deus" pairavam acima dos direitos humanos. Uma sociedade sacral ou Cristandade seria aquela em que fé e nacionalidade eram conceitos mutuamente identificados e o catolicismo a religião oficial de Estado. A idéia de Cristandade, ou seja, de unidade entre fé e nacionalidade, foi mantida por meio de dois mecanismos: pela 
ficiar e para fazer do Brasil um país evangélico - fazer da população brasileira uma que siga os princípios de conduta considerados evangélicos (p.ex., os grandes vícios e pecados sociais não seriam mais aceitos: divórcio, alcoolismo, homossexualidade e os demais pecados sexuais, corrupção). Em geral, os evangélicos não têm um projeto para o Brasil - como também não o tem a população brasileira como um todo, nem os detentores do poder estatal de plantão. Por um lado, isso nos ajuda a diluir o modelo de cristandade. Por outro, nos coloca na dependência de projetos políticopartidários sem identificação explícita com uma visão cristã da vida da nação. O principal desafio que nos confronta é a construção de projeto, o qual, porém, precisa ser teológico, e não ideológico, vacinado contra as tentações da estrutura de Cristandade ${ }^{15}$.

Inquisição em que possíveis rupturas na fé e, por extensão, na unidade nacional eram coibidas; por meio da Guerra Santa em que se combatiam os inimigos da pátria e, por conseguinte, da religião. Embora a mensagem cristã fosse tratada como universal, alguns povos, sucessivamente, passaram a atribuir-se os privilégios de encarregados de determinada missão, que tomava as feições de uma autêntica "cruzada". Essa idéia de Cristandade era polarizada em determinados princípios, que fundamentaram a ordem social e simultaneamente garantiram a estabilidade e expansão dos povos." (ZULIAN, Rosângela W. Identidade e Experiência: Uma Escola confessional na República Velha. Curitiba: Champagnat, 2005, p. 49.)

${ }^{15}$ Mesmo isto, porém, não é garantia de opções políticas adequadas, como reconheceu Foucault, a partir de uma conversa com Habermas sobre Heidegger e o nazismo, "é preciso tomar consciência de vários fatos: a pouca ligação 'analítica' entre uma concepção filosófica e a atitude política concreta daquele que a sustenta; as 'melhores' teorias não constituem uma proteção eficaz contra escolhas políticas desastrosas; alguns grandes temas como o 'humanismo' podem servir para qualquer coisa, assim como para mostrar com que gratidão Pohlenz teria saudado Hitler." (FOUCAULT, Michel. "Política e ética: uma entrevista". In: 
Um dos principais motivos internos dessa situação é a falta de exegese e teologia autóctones tendo como sujeitos os cristãos e as cristãs em suas comunidades. A reflexão teológica que se faz em círculos evangélicos ainda se dá predominantemente entre o clero e nas instituições teológicas que estão voltadas prioritariamente para a formação do clero protestante. Pensamento ético sem teologia se reduz à construção de códigos de conduta ou, na pior das hipóteses, em condenações moralistas dos outros - de modo que não nos deveríamos surpreender com as atitudes éticas e as posturas morais das membresias de comunidades evangélicas ${ }^{16}$. O outro lado da moeda desse motivo pode ser localizado na própria tradição doutrinária evangélica que, enquanto afirma a salvação pela graça, trata a santidade a partir da Lei divina, de modo que ser santo se torna um dever, uma obrigação. A partir de tal conceito de santidade, a ética inevitavelmente se reduz às dimensões pessoal e religiosa. Podemos traçar as raízes dessa noção de santidade à implantação do protestantismo de missões no Brasil, que desenvolveu a ideia de santidade a partir da oposição ao comportamento cotidiano dos brasileiros - considerado como "católico-romano" e, assim, o oposto do que deveria ser o comportamento de evangélicos.

Passo, a seguir, a refletir teologicamente sobre um caminho mais viável para a ética de evangélicos.

\footnotetext{
MOTTA, Manoel B. da (org.). Foucault: Ética, sexualidade, política. Ditos \& Escritos V. Rio de Janeiro: Forense Universitária, 2004, p. 219).

${ }^{16}$ Para superar isso, é preciso, primeiro, perceber que a "ética cristã é a prática de uma disciplina que visa transformar o eu e o mundo na perspectiva e expectativa do Reino." (KEELING, Michael. Fundamentos da ética cristã. São Paulo: ASTE, 2002, p. 199).
} 


\section{Construindo uma ética da liberdade em amor}

\subsection{Uma cristologia da liberdade}

Se pensamos em uma ética cristã organicamente vinculada à teologia-espiritualidade-missão cristãs, em seguimento de Jesus Cristo e energizada pelo agir do Espírito, precisamos pensá-la a partir de uma teologia da liberdade. Podemos construir essa teologia da liberdade a partir dos escritos paulinos, especialmente da carta aos gálatas. Ofereço, a seguir, algumas linhas-mestras para a construção do conceito cristão da liberdade a partir de Gálatas.

A noção paulina da liberdade pressupõe que a humanidade esteja escravizada, conforme podemos constatar a partir dos seguintes textos: "Mas a Escritura sujeitou tudo ao pecado num cativeiro comum, a fim de que, pela fidelidade de Jesus Cristo, a promessa fosse cumprida para os que crêem. Antes da chegada da fé, nós éramos mantidos em cativeiro, sob a lei, em vista da fé que devia ser revelada" (G1 3.22s); "E nós, igualmente, quando éramos crianças sujeitas aos rudimentos do mundo, éramos escravos" (Gl 4.3); "outrora, quando não conhecíeis a Deus, estáveis escravizados a deuses que, por sua própria natureza, não o são..." (Gl 4.8). Esta descrição do cativeiro destaca os elementos que escravizam a humanidade: pecado, lei (de Deus), rudimentos do mundo, falsos deuses. Estes poderes que escravizam o ser humano são tão poderosos que este não pode se autolibertar, precisando, portanto, de um Libertador.

Entretanto, esses poderes escravizadores não são capazes de eliminar a nossa "humanidade", uma vez que fomos criados à imagem e semelhança de Deus (cf. Gn 1.26-28). Entra, aqui, o paradoxo paulino (e neotestamentário), de que a humanidade não pode se libertar, mas Deus também não pode libertar a 
humanidade sem a participação desta - a libertação não pode ser um ato divino que elimine a responsabilidade do ser humano (uso o termo aqui em um duplo sentido: o mais comum de "dever", e o mais denso de "ser capaz de responder a"). Dessa maneira, a condição humana de escravidão exigiu que o Libertador vivesse uma vida humana plenamente entregue ao Pai, de forma a revelar não só o amor do Pai, como também a plena humanidade desejada pelo Criador. Assim, a liberdade é conferida à humanidade mediante a integralidade da vida, morte e ressurreição de Cristo. Quatro características principais descrevem a ação libertadora do Cristo ${ }^{17}$ :

(1) Jesus Cristo liberta a humanidade, assumindo a própria condição humana de escravidão, e criando uma espaçotemporalidade para a ação colibertadora do Espírito: "mas, vindo a plenitude dos tempos, Deus enviou seu Filho, nascido de mulher, nascido debaixo de lei, para resgatar os que estavam debaixo de lei, a fim de recebermos a adoção de filhos. E, porque sois filhos, Deus enviou aos nossos corações o Espírito de seu Filho, que clama: Aba, Pai. Portanto já não és mais servo, mas filho; e se és filho, és também herdeiro por Deus" (G1 4.4-7). Jesus, nascido de mulher e sujeitado à Lei é o "humano" que, vocacionado (enviado) por Deus, liberta a humanidade. Jesus é Libertador mediante a sua solidariedade com

${ }^{7}$ Sintetizo aqui reflexões mais bem argumentadas e documentadas em: ZABATIERO, J. P. T. "Construindo a identidade messiânica de Jesus: uma leitura sócio-semiótica de Marcos 1,1,-3,35". In: Perspectiva Teológica. Belo Horizonte: FAJE, v. 38, n. 104, 2006, p. 65-87; ZABATIERO, J. P. T. "A redenção que há em Cristo Jesus". In: Pensador Cristão. Maringá, v. 10, 2002, p. 83-88; ZABATIERO, J. P. T. Fundamentos da Teologia Prática. 2. ed. São Paulo: Mundo Cristão, 2008; e ZABATIERO, J. P. T. “Para que somos salvos?”. In: ZABATIERO, Júlio P. T. (Org.). Teologia Sistemática. São Paulo: Edições Vida Nova, 2006, p. 101-120. 
a humanidade na escravidão que caracteriza a nossa condição. Como Filho encarnado de Deus, Jesus assume solidariamente a escravidão humana para que possamos, Nele, sermos tornados filhos adotivos de Deus - deixamos de ser escravos e nos tornamos filhos e herdeiros de Deus - herdamos a vida! Paulo faz uso da legislação romana sobre a adoção de escravos, que, ao assumir a condição de filhos de um homem livre, também assumiam a sua liberdade. A nova filiação a Deus, em Cristo, é concretizada na vida de cada pessoa mediante o Espírito de filiação que o Pai envia para consolidar a identidade filial do ser humano.

(2) Em segundo lugar, Jesus Cristo liberta a humanidade mediante a sua fidelidade (fé) a Deus - G1 2.16 (cp. G1 3.22; Rm 3.22,26): "Sabemos entretanto que o homem não é justificado pelas obras da lei, mas somente pela fé em Cristo, a fim de sermos justificados com base na fidelidade de Cristo e não com base nas obras da Lei, porque pelas obras da lei ninguém será justificado". A fonte discursiva véterotestamentária desta afirmação paulina é dupla: (a) Paulo interpreta a Lei como posterior à promessa de Deus a Abraão de que nele seriam abençoadas todas as famílias da terra - Gl 3.17s; (b) Paulo interpreta a vida justa - livre - como a vida do fiel a Deus (Habacuque 2.4 - no hebraico, o termo que costumeiramente se traduz por fé denota, primariamente, fidelidade).

Em que consistiu a fidelidade de Cristo, mediante a qual a humanidade é liberta? Consiste em sua resposta completa e plena à missão que lhe foi confiada pelo Pai que o vocacionou/ enviou (Gl 4.4ss). O fundamento de nossa liberdade é a fidelidade de Cristo, e isto é determinante para uma correta compreensão de nossa libertação - bem como nos ajuda a entender porque na tradição protestante se pode passar, sutilmente, da justificação pela fé para a santificação pela lei. Isto ocorre sempre que se confunde a fé em Cristo com o fundamento da 
salvação (a fidelidade de Cristo). A fé em Cristo é o meio pelo qual recebemos a salvação, respondendo à vocação do Evangelho da liberdade. O fundamento da libertação é a fidelidade de Cristo a Deus o Pai, que torna presente na história - chegada a plenitude dos tempos - a graça libertadora de Deus, agora disponível a todos os povos e não só aos descendentes físicos de Abraão.

(3) Em terceiro lugar, Jesus é o Libertador da humanidade porque assume a condição de maldito sob a Lei (G1 3.12-14). A lei, de origem divina, partilha da ambiguidade histórica da condição humana. Proposta como guia para a vida em liberdade na aliança com Deus (cf. Dt 10.12-16), a Lei escraviza porque obriga a pessoa a guardar todas as suas prescrições e determinações, o que é impossível à humanidade escravizada pelo pecado. Ao invés de meio de salvação, a Lei se torna instrumento de morte, ao colocar sob o jugo de sua maldição toda a humanidade ( $\mathrm{Rm} 2.17-29 ; 3.23)$. Em sua vida terrena e morte na cruz, Jesus assume a maldição que recaía sobre a humanidade, libertando-a da maldição da Lei. Desta forma, abre o caminho da promessa (da bênção abraâmica, Gn 12.1-4) a toda a humanidade. Doravante, o acesso à promessa é efetuado mediante a fé, pela qual a pessoa recebe o Espírito Santo prometido, com base na fidelidade de Jesus Cristo (cf. Gl 3.1-5) - e torna-se, assim, livre.

(4) Como Libertador divino-humano da humanidade, Jesus Cristo abre a possibilidade de uma vida de plena liberdade: "Para a liberdade Cristo nos libertou; permanecei, pois, firmes e não vos dobreis novamente a um jogo de escravidão" (G1 $5,1)$. Viver em liberdade não é, porém, um tranquilo projeto de vida - as tentações para voltar ao seguro e confortável caminho da escravidão são poderosamente sedutoras - seja a escravidão à Lei, ao pecado, à carne ou aos falsos deuses. A vida em Cristo é vivida na tensão escatológica da realização ainda 
não-realizada. Somente na fidelidade perseverante ao Cristo, no Espírito (Gl 2.20; 3.1-5), é que se pode viver em plena liberdade. Unem-se, então, teologia, espiritualidade e ética,"pois o que é a ética senão a prática da liberdade, a prática refletida da liberdade?"18

\subsection{Uma ética da liberdade em amor}

Conceber a ética cristã como ética de liberdade nos ajuda a reconfigurar a unidade entre teologia, espiritualidade e ética. Em primeiro lugar, porque faz parte da estrutura da liberdade humana a tomada de decisões a partir de razões e motivos deliberados: "uma vontade se configura - por mais imperceptivelmente que se faça algo - no curso de uma série de deliberações. E, dado que uma decisão somente amadurece como consequência de um conjunto de considerações - por mais voláteis e confusas que sejam - somente nos experimentamos a nós mesmos como pessoas livres em ações realizadas mais ou menos conscientemente". ${ }^{19}$ Fica evidente, a partir desta descrição da liberdade, o vínculo entre ética da liberdade e teologia - é mediante a reflexão teológica, em especial, que uma comunidade cristã define as razões e motivos para tomar decisões e agir.

Por outro lado, o vínculo entre ética da liberdade e espiritualidade se encontra na junção entre liberdade e amor, na medida em que a liberdade da comunidade cristã é liberdade

${ }^{18}$ FOUCAULT, Michel. "A ética do cuidado de si como prática da liberdade". In: MOTTA, Manoel B. da (org.). Foucault: Ética, sexualidade, política. Ditos \& Escritos V. Rio de Janeiro: Forense Universitária, 2004, p. 267.

${ }^{19}$ HABERMAS, Jürgen. “Libertad y determinismo". In: Entre naturalismo y religión. Barcelona: Paidós, 2006, p. 163. 
para amar, pois a fé "age pelo amor" (G1 5.6), a partir do que se estabelece o imperativo ético: "Porque vós, irmãos, fostes chamados à liberdade. Mas não useis da liberdade para dar ocasião à carne, antes pelo amor servi-vos uns aos outros. Pois toda a lei se cumpre numa só palavra, a saber: Amarás ao teu próximo como a ti mesmo" (G1 5.13-14). Livres da lei e dos ídolos, podemos viver na liberdade do amor - que é o fruto do Espírito da promessa, e o verdadeiro cumprimento da Lei $^{20}$. Como ética da liberdade cristã, é uma ética da liberdade em amor. A prática cristã da liberdade equivale à prática do amor como o eixo da ética e espiritualidade cristãs. Enquanto ética da liberdade em amor, é ética da graça, não da lei; da possibilidade, não do dever, pois é, afinal de contas, a expressão da própria vida enquanto dádiva do Deus que é amor (I Jo 4,8). ${ }^{21}$

20 'Uma ética em perspectiva luterana é, assim, ética da fé ativa no amor, ética do cuidado, ética da liberdade. Seu fundamento está na percepção das relações concretas da vida como geradoras e foco da existência ética. É destas relações, mais precisamente, do Deus e das pessoas com as quais nos relacionamos na concreticidade da existência que nos vem a interpelação ética. A dinâmica destas relações, baseadas no amor que tem origem na fé no amor que Deus demonstrou pela humanidade, é incorporada de tal modo que dali surge a energia que se transforma em existência ética, a qual, citando Lutero uma última vez, 'não pergunta se há boas obras a fazer, e sim, antes que surja a pergunta, ela já as realizou e sempre está a realizar' (Prefácio à Epístola de São Paulo aos Romanos, OSel 8:133)." (MUELLER, Enio R. "Fundamentos da ética em Lutero". In: WACHHOLZ, Wilhelm (coord.) Identidade Luterana e Ética. Anais do III Simpósio sobre identidade evangélico-luterana. São Leopoldo: EST, 2005, p. 26).

21 "não defini o amor, pois isso é impossível - não há nenhum princípio mais elevado pelo qual se possa defini-lo. É a própria vida na sua unidade real. [...] E este é o significado da ética: a expressão das maneiras em que o amor se encarna, e a vida é preservada e salva" (TILLICH, Paul. Morality and Beyond. New York: Harper \& Row, 1963 , p. 94s). 
O amor cristão não é o amor romântico de pessoas apaixonadas, nem o amor recíproco da amizade, mas a fonte da prática do bem a favor do outro, da pessoa necessitada (I Jo $3.16-19 ; 4.20-21)$. Nas origens da tradição reformada, o amor era biblicamente entendido como prática concreta da bondade, o que hoje chamaríamos de solidariedade: "Sim, onde estiver a fé, ela não consegue se refrear, ela se comprova, irrompe e confessa e ensina este evangelho diante das pessoas e por ele arrisca a sua vida. E tudo que ela vive e faz, destina-o ao proveito do próximo, para lhe ajudar, não só que ele alcance semelhante graça, mas também no que tange o corpo, propriedade e honra, como ela vê que Cristo lhe fez, seguindo, portanto, o exemplo de Cristo"22. Entendida a liberdade cristã como prática do amor, não podemos senão pensá-la em sua possibilidade impossível, não podemos senão pensá-la sempre além das definições e codificações, pois a liberdade em amor se revolta contra quaisquer tentativas de aprisioná-la em um código de conduta. Como ética da possibilidade impossível da vida em liberdade amorosa, a ética evangélica pode ser descrita, em termos foucaultianos, como uma estética - um projeto de viver, e não como uma teoria da obediência: "a ideia de uma moral como obediência a um código de regras está desapare-

${ }^{22}$ LUTERO, Martinho. Pelo evangelho de Cristo: obras selecionadas de momentos decisivos da Reforma. Porto Alegre: Concórdia, São Leopoldo: Sinodal, 1984, p. 176. Ver, também: "Além do que acima foi dito, para que não nos cansemos de fazer o bem, o que de outra forma aconteceria em pouco tempo, devemos recordar o que o apóstolo Paulo logo adiante diz: 'o amor é paciente ... não se exaspera'. O Senhor ordena que façamos o bem a todos, sem exceção, apesar do fato de que em sua maior parte são indignos, se os julgarmos segundo os seus próprios méritos." (CALVINO, João. As Institutas da Religião Cristã: edição especial com notas para estudo e pesquisa. São Paulo: Cultura Cristã, 2006, vol. 4, p. 190). 
cendo, já desapareceu. E a esta ausência de moral corresponde, deve corresponder uma busca que é aquela de uma estética da existência" ${ }^{23}$.

Viver a liberdade cristã em amor em sociedades democráticas se expressa, não só mediante atos pessoais de bondade ao próximo, mas também (e especialmente) através de atos comunitários de bondade com vistas à construção de uma sociedade melhor - uma sociedade que encarne historicamente os sinais do Reino de Deus que permanentemente se aproxima na ação do povo que segue a Jesus Cristo, na força do Espírito. Em termos ético-teológicos, a liberdade se orienta pelo futuro de Deus que irrompe na história humana:

liberdade é a paixão criativa pelo possível. Liberdade não é apenas voltada para as coisas como elas são, como na dominação. Nem é direcionada apenas à comunidade de pessoas como elas são, como na solidariedade. Ela se direciona para o futuro, pois o futuro é o campo desconhecido das possibilidades, enquanto o presente e o passado representam esferas familiares de realidades. [...] Assim como Martin Luther King, temos visões e sonhos de outra vida, uma vida curada, justa e boa. Exploramos as possibilidades do futuro a fim de realizar esses sonhos, visões e projetos. Todas as inovações culturais e sociais pertencem a esta esfera de liberdade para o futuro. ${ }^{24}$

${ }^{23}$ FOUCAULT, Michel. "Uma estética da existência". In: MOTTA, Manoel B. da (org.). Foucault: Ética, sexualidade, política. Ditos \& Escritos V. Rio de Janeiro: Forense Universitária, 2004, p. 290.

${ }^{24}$ MOLTMANN, Jürgen. God for a secular society. The Public relevance of theology, Minneapolis, Fortress Press, 1999,p. 159s. 


\subsection{Identidade cristã e a ética da liberdade}

Por fim, é importante indicar a relação entre a ética da liberdade em amor e a construção da identidade cristã. A identidade do povo de Deus não pode ser construída adequadamente se, de novo, separarmos teologia, espiritualidade e ética. A identidade cristã não pode ser pensada e construída apenas a partir de um desses polos do existir cristão, sob pena de ser uma identidade imatura e conformada aos modos ocidentais de relação com a temporalidade: voltada ao passado, no tradicionalismo; voltada a um futuro construído exclusivamente por mãos humanas, como na modernidade; ou focada no presente eternizado, como na pós-modernidade. Uma vez que a vida cristã é vivida na tensão escatológica, a futuridade deve ser vista como o modo de ser da existência em Cristo. A abertura ao futuro do Reino é o reconhecimento de que a plenitude da vida ainda está em processo de realização e a utopia do Reino é o seu norte, a sua estrela orientadora ${ }^{25}$. Ser cidadão, consequentemente, é ser uma pessoa criativa nas relações sociais, em busca da construção de uma sociedade cada vez mais justa, inclusiva e solidária. ${ }^{26}$ Entendida desta forma, a ética da liber-

25 "Ela [a liberdade] está orientada para o futuro, o futuro de Deus que há de vir. Pois o futuro de Deus é o reino sem limites das possibilidades criadoras, enquanto o passado é o reino limitado da realidade. A paixão criadora está sempre orientada para o projeto de um tal futuro. ... Esta visão futurista da liberdade por muito tempo deixou de ser percebida, porque a liberdade da fé cristã não era entendida como participação no agir criador de Deus e porque a cristandade era dominada mais pelo respeito religioso do que pela esperança messiânica. Mas na verdade, liberdade na fé é criatividade que rompe as barreiras, nas ante-salas do possível" (MOLTMANN, Jürgen. O Espírito da Vida. Petrópolis: Vozes, 1999, p. 119).

26 "Qualquer pessoa que em pensamento, palavra e ação transcende o presente na direção do futuro é verdadeiramente livre. O futuro é o livre espaço da liberdade criativa. [...] É um acontecer. Somente temos 
dade em amor se configura como a própria identidade do ser cristão. ${ }^{27}$

O ponto de partida da experiência do tempo na fé cristã é a tensão escatológica do jálainda-não, é a futuridade de Deus que invadiu o presente (passado para nós) da história e o preencheu de um novo sentido e de uma nova dinâmica. A identidade cristã não se configura, nem a partir do passado, nem a partir do presente - mas do futuro que se fez história em Jesus. Não se configura nem a partir do tendo-sido, nem do sendo, mas do poder-vir-a-ser que, a partir do passado, já se faz presente historicamente. Identidade, então, não se resgata (fixação no passado), nem se perde (temor do presente), mas se constrói. Não será esta uma tradução fiel do princípio protestante de que a Igreja Reformada está sempre se reformando?

Destaco dois textos neotestamentários que podem nos ajudar a descrever a futuridade como modo de ser da identidade e da ética cristãs: $\mathrm{Hb} 11.1$ e $\mathrm{Cl} 3.1-4$. A clássica definição neotestamentária da fé, em Hebreus 11.1, é um texto reconhecidamente complexo. O que é mais claro no versículo é a orientação da fé para o futuro divino prometido ao ser

nossa liberdade criativa no processo de libertação. Nunca somos livres de uma vez por todas, mas continuamente nos tornamos livres. E somente o povo que faz uso da liberdade permanece livre. [...] Na história, se nós seguimos as memórias da Bíblia, encontramos liberdade no contínuo êxodo da escravidão e letargia, e na longa marcha através do deserto; mas não ainda na terra prometida, que é o 'fim da história'. Liberdade é como o maná no deserto. Não pode ser armazenada. Somente podemos confiar que o amanhã estará lá novamente. Assim, temos de usar nossa liberdade a cada dia." (MOLTMANN, Jürgen. God for a secular society. The Public relevance of theology. Minneapolis: Fortress Press, 1999, p. 160s.)

${ }^{27}$ Retomo e atualizo discussão de: ZABATIERO, J. P. T. "O Desafio da construção da identidade". In: Revista Teológica. Campinas: STPS, v. 61, n. 52,2001 , p. $25-30$. 
humano e antecipado escatologicamente em Cristo. Trago três comentários do texto que apontam possibilidades de compreensão da futuridade como modo de ser da identidade cristã: "Fé verdadeira, isto é, fé que se mantém até o fim (Hb 10.39), é a garantia (objetiva, não subjetiva) da salvação (certeza das coisas que se esperam). O crente é assegurado de que irá receber aquilo que ainda não está presente, mas que é prometido por Deus (v. especialmente Hb 6.12.15; 11.33)"'28. Como expressão da tensão escatológica, a fé cristã é fé perseverante:

"Tendo em vista que a preocupação aqui é com a manutenção de fidelidade perseverante em uma época de provação, e visa, provavelmente, apoiar a manutenção da crença descrita em 10.38, elenchos (com hypostasis) deve ser visto como o oposto da postura de retraimento e languidez. Um lugar para resistir e ficar estável só pode ser encontrado no mundo invisível que é o objeto da esperança e que, para a fé, é a única realidade. Neste contexto, o autor pode 'definir' a fé como 'o fundamento de realidade para o objeto das esperanças da pessoa e a prova das coisas que não podem ser vistas" 29 . Consequentemente, a fé vivida é a concretização do possível em sua impossibilidade: "Na primeira oração paralela, hypostasis deveria ser traduzida, de acordo com o uso da palavra no desenvolvimento da tradição filosófica, como realização, conduzindo à afirmação paradoxal: 'fé é a realização daquilo que se espera e a prova de coisas que não podem ser vistas'." 30

${ }^{28}$ HOLLANDER, Horst. W. "hypostasis". In: Exegetical Dictionary of the New Testament. Grand Rapids: Eerdmans, 2002, vol. 3, p. 407.

${ }^{29}$ PORSCH, Fredrik. "elenchos". In: Exegetical Dictionary of the New Testament. Grand Rapids: Eerdmans, 2002, vol. 1, p. 428.

${ }^{30}$ BARTH, Gerhard. "pistis “. In: Exegetical Dictionary of the New Testament. Grand Rapids: Eerdmans, 2002, vol. 3, p. 96. 
Cl 3.1-4 é a parte final da discussão de Paulo a respeito de uma proposta de ética cristã centrada no dever, uma interpretação judaico-mistérica da fé cristã $(\mathrm{Cl} 2.16-23)$. O padrão ético é encontrado nas ordenanças e mandamentos da lei, sintetizadas nas prescrições alimentares judaicas. Para o judaísmo antigo, as prescrições alimentares eram extremamente importantes, na medida em que definiam a identidade do Judaísmo em oposição ao Helenismo. Em I Macabeus 1.62-63 lemos: "muitos, em Israel, permaneceram firmes e de coração resoluto, não comeram comida impura. Preferiram morrer do que ser contaminados pela comida, ou profanarem a santa aliança; e eles morreram."

A observância das regras alimentares era vista como marca fundamental de lealdade à nação e à religião, como podemos ver nos contos populares judeus da época, nos quais os heróis, ou heroínas, são apresentados como modelos de piedade reconhecidos por Deus, precisamente em termos de sua recusa em comer a comida dos gentios (Dn 1.3-16; 10.3; Tobias 1.10-12; Judite 12.1-19; Acréscimos a Ester 14.17; José e Asenate 7.1; 8.5). [...] Em síntese, a observância de várias restrições relativas à alimentação era essencial para a identidade e o estilo de vida judaicos na diáspora. ${ }^{31}$

Além da alimentação, a ética estava vinculada à observância do calendário litúrgico judaico ("dias de festa, lua nova e sábado"). Se festas e luas novas eram cerimônias presentes em tradições religiosas distintas, o Sábado era a marca espe-

${ }^{31}$ DUNN, James. D. G. The Epistles to the Colossians and to Philemon. A commentary on the Greek text. Grand Rapids: Eerdmans, 1996, p. 172. 
cificamente judaica. Isto sugere que os três termos se referem a celebrações judaicas, o que é confirmado pela ocorrência dos três termos juntos em vários textos do Antigo Testamento, p.ex.: I Cr 23.31; II Cr 2.3; 31.3; Ne 10.33; Is 1.13-14; Ez 45.17; Os 2.11; presentes também em textos de Qumran: CD 3.14-15; 1QS 9.26-10.8.

A resposta paulina, em $\mathrm{Cl} 3.1-4$, é a proposta de uma ética da liberdade em futuridade: no v. 1 afirma-se a nossa ressurreição com Cristo, no presente, que demanda de nós a "busca das coisas do alto", ou seja, as coisas que pertencem ao senhorio de Cristo, exaltado à destra de Deus. No v. 2, as coisas do alto são contrastadas com as terrenas, nós diríamos "seculares", e o motivo desse contraste é dado no v. 3 "morrestes, e a vossa vida está oculta com Cristo, em Deus". Para nosso argumento, este verso é fundamental, na medida em que aponta para o caráter fragmentário, parcial de nossa percepção da identidade cristã no presente - ainda não sabemos o que efetiva e realmente somos - somente "quando Cristo, que é a vossa vida, se manifestar, sereis manifestos com ele em glória" (v. 4), o que torna evidente que o futuro do Reino de Deus é que determina o presente e a identidade cristã - e, consequentemente, a ética da liberdade em amor. Como ética vivida na tensão escatológica, a ética evangélica não pode se reduzir a questão de normas, regras de conduta, ou mesmo princípios e valores. É uma ética do seguimento de Jesus e se insere no mistério do Cristo que transforma todas as coisas - ética da liberdade em amor é ética criativa na busca da semelhança com Cristo na vida pessoal e eclesial.

\section{CONCLUSÃO}

No caminho para se transformar em uma ética transformadora, fiel à tradição reformada e ao princípio protestante, a ética evangélica brasileira pode ser adequadamente enten- 


\section{4 | Revista Reflexus}

dida e descrita como uma ética da liberdade em amor - que supera a ética do dever e seus códigos de conduta e normas de comportamento; que supera a tentação da Cristandade e faça da cidadania de cristãos sinal da cidadania do Reino de Deus. Uma ética da liberdade em amor não pode ser "definida", mas perseguida permanentemente, mediante a busca incessante de concretização da unidade entre teologia, espiritualidade e ética - unidade que será primícias da futuridade de Deus e seu reino, na construção de melhores pessoas e melhores sociedades, caracterizadas pela liberdade e amor que constituem o modo de convivência com o Deus que faz aliança com sua criação para que ela tenha vida plena. 


\section{REFERÊNCIAS BIBLIOGRÁFICAS}

BARTH, Gerhard. "pistis ". In: Exegetical Dictionary of the New Testament. Grand Rapids: Eerdmans, 2002, vol. 3. BOVKALOVSKI, Etiane C. Homens e mulheres de Deus: modelos de conduta ética da IURD (1986-2001). Tese de doutorado defendida junto ao PPG em História da Universidade Federal do Paraná. Curitiba, 2005, inédita.

CALVINO, João. As Institutas da Religião Cristã: edição especial com notas para estudo e pesquisa. São Paulo: Cultura Cristã, vol. 4, 2006.

DUNN, James. D. G. The Epistles to the Colossians and to Philemon. A commentary on the Greek text. Grand Rapids: Eerdmans, 1996.

FOUCAULT, Michel. "A ética do cuidado de si como prática da liberdade". In: MOTTA, Manoel B. da (org.). Foucault: Ética, sexualidade, política. Ditos \& Escritos V. Rio de Janeiro: Forense Universitária, 2004.

FOUCAULT, Michel. "Política e ética: uma entrevista". In: MOTTA, Manoel B. da (org.). Foucault: Ética, sexualidade, política. Ditos \& Escritos V. Rio de Janeiro: Forense Universitária, 2004.

FOUCAULT, Michel. "Uma estética da existência". In: MOTTA, Manoel B. da (org.). Foucault: Ética, sexualidade, política. Ditos \& Escritos V. Rio de Janeiro: Forense Universitária, 2004. 
GRENZ, Stanley. A busca da moral. Fundamentos da ética cristã. São Paulo: Vida, 2006.

HABERMAS, Jürgen. "Libertad y determinismo". In: Entre naturalismo y religión. Barcelona: Paidós, 2006.

HABERMAS, Jürgen. "Racionalidad de uma forma de vida". In: REDONDO, Manuel J. (org.) Escritos sobre moralidad y eticidad. Barcelona: Paidós, 1991.

HOLLANDER, Horst. W. "hypostasis". In: Exegetical Dictionary of the New Testament. Grand Rapids: Eerdmans, vol. 3, 2002.

KEELING, Michael. Fundamentos da ética cristã. São Paulo: ASTE, 2002.

LIPOVETSKY, Giles. A sociedade pós-moralista. O crepúsculo do dever e a ética indolor dos novos tempos democráticos. Barueri: Manole, 2005.

LUTERO, Martinho. Pelo evangelho de Cristo: obras selecionadas de momentos decisivos da Reforma. Porto Alegre: Concórdia, São Leopoldo: Sinodal, 1984.

MOLTMANN, Jürgen. God for a secular society. The Public relevance of theology, Minneapolis, Fortress Press, 1999.

MOLTMANN, Jürgen. O Espírito da Vida. Petrópolis: Vozes, 1999.

MUELLER, Enio R. "Fundamentos da ética em Lutero". In: WACHHOLZ, Wilhelm (coord.) Identidade Luterana e Ética. Anais do III Simpósio sobre identidade evangélicoluterana. São Leopoldo: EST, 2005.

PORSCH, Fredrik. "elenchos". In: Exegetical Dictionary of the New Testament. Grand Rapids: Eerdmans, vol. 1, 2002. SOUZA, Jessé. "Democracia racial e multiculturalismo: a ambivalente singularidade cultural brasileira". In: Estudos Afro-Asiáticos. Rio de Janeiro, n. 38, dezembro de 2000, pp. 135-155. http://www.scielo.br/scielo.php?script=sci arttext\&pid=S0101-546X2000000200007\&lng=pt\&nrm=iso. 
THIELICKE, Helmut. Theological Ethics. Foundations. Philadelphia: Fortress Press, 1966.

TILLICH, Paul. Morality and Beyond. New York: Harper \& Row, 1963.

ZULIAN, Rosângela W. Identidade e Experiência: Uma Escola confessional na República Velha. Curitiba: Champagnat, 2005 . 